\title{
Pestivirus spillover effect: molecular detection of bovine viral diarrhea virus in domestic and feral pigs ${ }^{1}$
}

\author{
Dragoș Constantin Aniță², Emilia Popa ${ }^{3}$, Adriana Aniță2* (D), \\ Luanda Elena Oșlobanu ${ }^{2}$ and Gheorghe Savuța ${ }^{2}$
}

\begin{abstract}
Aniță D.C., Popa E., Aniță A., Oșlobanu L.E. \& Savuța G. 2020. Pestivirus spillover effect: molecular detection of bovine viral diarrhea virus in domestic and feral pigs. Pesquisa Veterinária Brasileira 40(6):479-483. Faculty of Veterinary Medicine, University of Agricultural Sciences and Veterinary Medicine Iasi, 8 Mihail Sadoveanu Alley, 700489, Iași, Romania. E-mail: aeanita@uaiasi.ro

Pestivirus infections are important in the livestock industries, with infection occurring in cattle, sheep and pigs. The Pestivirus genus of the family Flaviviridae, includes four recognized species: bovine viral diarrhea virus 1 (BVDV-1), bovine viral diarrhea virus 2 (BVDV-2), border disease virus (BDV), and classical swine fever virus (CSFV). All pestivirus species can infect pigs, therefore accurate and specific pestivirus detection and differentiation is of great importance to assure control measures in swine populations. The aim of the study was the molecular detection of different pestiviruses in domestic and feral pigs. A total of 527 samples (92 pigs and 435 wild boars) were tested for pestiviruses detection using molecular assays. Eleven positive samples ( 6 wild boars and 5 domestic pigs) were identified using panpestivirus primers targeting the 5'- UTR region of the pestivirus RNA genome. Further all the positive samples were sequentially tested for detection of CSFV, BVDV-1 and BVDV-2 using specific primers. All RNAs were identified as positives for BVDV-1 and no amplification signals were obtained from BVDV-2 and CSFV. The current detection of BVDV-1 in clinical swine specimens highlights the important risk factor of swine population as reservoir and consequently carrier for BVDV.
\end{abstract}

INDEX TERMS: Pestivirus, molecular detection, bovine viral diarrhea virus, domestic pigs, feral pigs, BVDV, pigs, wild boar, PCR, wildlife animals.

RESUMO.- [Efeito spillover de pestivírus: detecção molecular do vírus da diarreia viral bovina em suínos domésticos e javalis.] As infecções por pestivírus são importantes nas indústrias pecuárias, com infecções em bovinos, ovinos e suínos. $\mathrm{O}$ gênero Pestivirus da família Flaviviridae inclui quatro espécies reconhecidas: vírus da diarreia viral bovina 1 (BVDV-1), vírus da diarreia viral bovina 2 (BVDV-2), vírus da doença de fronteira (VDF) e vírus da peste suína clássica (VPSC). Todas as espécies de pestivírus podem infectar porcos, portanto a detecção e diferenciação precisas e específicas de pestivírus são de grande importância para garantir medidas de controle nas populações suínas. 0 objetivo do estudo foi

\footnotetext{
${ }^{1}$ Received on October 21, 2019.

Accepted for publication on February 19, 2020.

${ }^{2}$ Faculty of Veterinary Medicine, University of Agricultural Sciences and Veterinary Medicine Iasi, 8 Mihail Sadoveanu Alley, 700489, Iași, Romania. *Corresponding author: aeanita@uaiasi.ro

${ }^{3}$ Sanitary-Veterinary and Food Safety Laboratory Iasi County, 10 Mihail Sadoveanu Alley, 700489 Iași, Romania.
}

a detecção molecular de diferentes pestivírus em suínos domésticos e javali. Um total de 527 amostras ( 92 porcos e 435 javalis) foram testados para detecção de pestivírus usando ensaios moleculares. Onze amostras positivas (6 javalis e 5 porcos domésticos) foram identificadas usando iniciadores de panpestivírus visando a região 5'-UTR do genoma do RNA do pestivírus. Além disso, todas as amostras positivas foram testadas sequencialmente para detecção de VPSC, BVDV-1 e BVDV-2 usando iniciadores específicos. Todos os RNAs foram identificados como positivos para BVDV-1 e nenhum sinal de amplificação foi obtido do BVDV-2 e CSFV. A detecção atual do BVDV-1 em amostras clínicas de suínos destaca o importante fator de risco da população suína como reservatório e consequentemente portador do BVDV.

TERMOS DE INDEXAÇÃO: Pestivírus, detecção molecular, vírus da diarreia viral bovina, suínos domésticos, javalis, BVDV, porco, javali, PCR, suínos, animais selvagens. 


\section{INTRODUCTION}

The genus Pestivirus in the family Flaviviridae currently comprises four species, bovine viral diarrhea virus 1 (BVDV-1), bovine viral diarrhea virus 2 (BVDV-2), border disease virus (BDV) and classical swine fever virus (CSFV) (Simmonds et al. 2017). Pestiviruses infect pigs and ruminants with significant economic impact (Moennig \& Becher 2015) but have also been detected in wild ruminants and wild boar. Pestiviruses are sub-divided according to their host but serological crossreactivity has been demonstrated between all pestiviruses (Wieringa-Jelsma et al. 2006). While CSFV is restricted to pigs, the other Pestivirus species have been recovered from hosts of a greater variety. There are less clear-cut differences in host range. BVDV-1, BVDV-2 and BDV can infect a wide range of ruminants, including cattle, sheep, goats, and a number of wild ruminants as well as pigs. A number of atypical pestiviruses have been described originating from giraffe, reindeer, pronghorn antelope and from fetal calf serum ("HoBi" virus) (Liu et al. 2009). Recently, another pestivirus, "Bungowannah", was isolated from pigs (Kirkland et al. 2007). Also, newly identified atypical porcine pestivirus (APPV) was demonstrated to be the causative agent of the neurological disorder "congenital tremor" in newborn piglets (Jin et al. 2017).

Pestiviruses are highly variable RNA viruses, their number increasing constantly. RNA viruses are characterized by high mutation rates and the lack of proofreading activity of RNA-dependent RNA polymerases is believed to be the main driving force for the generation of altered genomic sequences. Evolution of pestiviruses occurs by point mutation and by homologous recombination within species (Weber et al. 2015). A growing number of novel pestiviruses has been discovered in domestic and wild species in the last two decades (Smith et al. 2017). Members of the different Pestivirus species can be distinguished from each other by the presence of sequence motifs in the $5^{\prime}$-untranslated region that are involved in RNA secondary structures (Giangaspero \& Harasawa 2011). The secondary structure of the 5'-UTR is divided into four domains, the last one encompassing the two thirds in the 3' region of the 5'-UTR, is responsible for translational, transcriptional and replicational events in pestiviruses. Therefore, random mutations at the 5'-UTR have a high probability of incompatibility with viral survival (Giangaspero et al. 2008).

\section{MATERIALS AND METHODS}

During 2014-2016, tissue samples from 527 pigs: 92 backyard pigs respectively 435 wild boars were collected. From each animal were sampled spleen, tonsils and lymph nodes (mesenteric and retropharyngeal), followed by automatically disruption of $100 \mathrm{mg}$ of pooled tissue samples suspended in $900 \mu$ I DPBS 1X (Gibco, Paisley, Scotland, UK) using MagNA Lyser (Roche, Mannheim, Germany). Total RNA was extracted from $200 \mu$ l supernatant using RNeasy Mini kit (QIAGEN GmbH, Hilden, Germany) according to the manufacturer's instructions.

Reverse transcription and PCR amplification of the viral RNA were done in one-step using the One-step RT-PCR Kit (QIAGEN GmbH, Hilden, Germany). The 5'UTR genes from the genome of pestivirus were PCR amplified. The 5'UTR genes from the pestivirus genome were amplified using the primers listed in the table below (Table 1).

At the beginning one-step RT-PCR was performed for all RNAs using described panpestivirus primers 324 and 326 (Vilcek et al. 1994). The amplification was carried out with $10 \mu \mathrm{l}$ RNA in a total volume of $50 \mu \mathrm{l}$. Sequentially for detection of CSFV, BVDV -1 and BVDV-2 were used three sets of primers for specific identification. The amplification was carried out in a total volume of $25 \mu \mathrm{l}$ comprised of $2 \mu \mathrm{l}$ RNA, OneStep RT-PCR (QIAGEN GmbH, Hilden, Germany) mix enzyme, $0,1 \mu \mathrm{M}$ of each primer, $5 x$ Buffer OneStep RT-PCR (QIAGEN $\mathrm{GmbH}$, Hilden, Germany), 10mM dNTP (QIAGEN GmbH, Hilden, Germany), $0,1 \mu \mathrm{l}$ of $40 \mathrm{U} / \mu \mathrm{l}$ RNAsin ribonuclease inhibitor. The thermal profile used consisted of: revers transcription $30 \mathrm{~min}$ at $50^{\circ} \mathrm{C}$, initial PCR activation step $15 \mathrm{~min}$ at $95^{\circ} \mathrm{C}, 45$ cycles of the following; $94^{\circ} \mathrm{C}$ for $45 \mathrm{sec}$, variable annealing temperature depending of the primer set used $\left(56^{\circ} \mathrm{C}\right.$ for panpestivirus primers $/ 58^{\circ} \mathrm{C}$ for BVDV$1 / 54^{\circ} \mathrm{C}$ for BVDV-2 and CSFV) for $45 \mathrm{sec}$ and extension at $72^{\circ} \mathrm{C}$ for $45 \mathrm{sec}$; and a final extension at $72^{\circ} \mathrm{C}$ for $7 \mathrm{~min}$. Each amplification was validated by the use of three positive controls: positive RNA for CSFV, BVDV-1 and BVDV-2. The commercial live vaccines containing BVDV-1 and BVDV-2 (Bovela ${ }^{\circledR}$ Boehringer Ingelheim, Germany) and classical swine fever virus (Rompestivac ${ }^{\circledR}$ Romvac, Romania) were used as positive controls for the RT-PCR reactions. The negative control used in order to check for possible contamination of the reagents was nuclease free water. The PCR products of $5^{\prime}$-UTR genes were separated by gel electrophoresis in $1.5 \%$ agarose gel stained with ethidium bromide. The fragments were visualized using a UV transilluminator (GelDoc BioRad, Marnes-la-Coquette, France). Positive amplicons were purified using Wizard ${ }^{\circledR}$ SV Gel and PCR Clean-Up System (Promega, USA). The DNA sequencing was performed at BaseClear B.V. (Leiden, The Netherlands). Nucleotide sequences were analysed and edited individually using Bioedit soft. Afterwards, the obtained sequences and sequences available in GenBank were aligned using Clustal W and the evolutionary tree was generated with MEGA 7 using the Neighbor-Joining method with a total of 1000 replications on the bootstrap.

The study was performed in accordance with the Directive 2010/63/EU regarding animal handling ethical guidelines. Animal samples (wild boar tissues samples) were collected during the

Table 1. Primer sequences and sizes of one step RT-PCR products

\begin{tabular}{|c|c|c|c|}
\hline Name & Sequence of the primers & PCR fragment & Reference \\
\hline 324 (forward) & 5' - ATGCCCWTAGTAGGACTAGCA - 3' & \multirow{2}{*}{$288 \mathrm{bp}$} & \multirow{2}{*}{ Vilcek et al. 1994} \\
\hline 326 (reverse) & 5' - TCA ACTCCATGTGCCATGTAC - 3' & & \\
\hline CSFV (forward) & 5' - CTAGCCATGCCCWYAGTAGG - 3 & \multirow{2}{*}{$420 \mathrm{bp}$} & \multirow{2}{*}{ Greiser-Wilke et al. 1998} \\
\hline CSFV-R (reverse) & 5' - CAGCTTCARYGTTGATTGT - 3' & & \\
\hline BVDV-1 (forward) & 5' - GGTAGCAACAGTGGTGAG-3' & \multirow{2}{*}{$211 \mathrm{bp}$} & \multirow{2}{*}{ Tao et al. 2013} \\
\hline BVDV-1 (reverse) & 5' - GTAGCAATACAGTGGGCC-3' & & \\
\hline
\end{tabular}


hunting seasons and according with EU and national low: The Law of hunting and protection of hunting fund no. 407/2006 and amendment Law no. 149/2015.

\section{RESULTS}

The pestiviruses genome includes a single, large, open reading frame (ORF) which encodes a polyprotein of approximately 3,900 amino acids. The ORF is flanked, at each end, by untranslated regions (UTRs). The genome is uncapped at its 5 '-terminus and the 5'-UTR contains an internal ribosomal entry site (IRES) which directs cap-independent translation initiation on the viral RNA (Fletcher \& Jackson 2002). High conservation of 5'UTR sequences is related to IRES formation. Using panpestivirus primers targeting the 5'-UTR region of the pestivirus RNA genome 11 positive animals out of 527 tested ( 6 wild boars and 5 backyard pigs) were detected (Table 2).

Further all RNAs were sequentially tested for the detection of CSFV, BVDV-1 and BVDV-2 using specific primers. All panpestivirus positives RNAs were identified as positives for BVDV-1 and no amplification signals were obtained from BVDV-2 and CSFV. The 5'-UTR (360-390 bases) is highly conserved among all members within the genus Pestivirus, yet use of specific primers for amplification of the $5^{\prime}$-UTR genes can readily distinguish BVDV-1 isolates from BVDV-2, CSFV and BDV isolates. (Ridpath \& Bolin 1998, Flores et al. 2002). To characterize BVDV-1 strains, the positive products were sequenced and analyzed. The characterization of viral strains circulating in swine population analyzed in this study is based on a $288 \mathrm{bp}$ fragment from 5'-UTR region. Two out of 11 positive samples were successfully sequenced. The sequences obtained have a 98\% nucleotide sequences homology with each other and clustered together based on alignment with the best hits of our sequences in GenBank. Phylogenetic analysis showed also that the Romanian sequences formed a branch with a BVDV-1 strain from France and one isolated in Turkey (Fig.1).

\section{DISCUSSION}

Since different pestiviruses are closely related, both immunologically and genetically, the ruminant's pestivirus infections in swine can result into a false diagnosis. Bovine viral diarrhea is an important infectious disease of cattle due to the specific nature of virus epidemiology and pathogenesis together with economical losses that follows a herd infection. BVDV transmission to pigs usually requires direct contact with cattle or sheep. Other possible methods by which infection may be transmitted include exposure of swine to ruminant faeces or feeding of un-pasteurised cow's milk. The three prerequisites for animal infectious disease (the source of infection, transmission route and sensitive animals) must be well understood in order to control and eradicate pestiviruses.

The objective of this work was to evaluate the role of swine (domestic and feral) as reservoir of pestiviruses in general and bovine viral diarrhea virus in particular, persistent infection being described in pigs (Terpstra \& Wensvoor 1997). Thus 527 pigs and wild boars were tested for pestivirus using one step RT-PCR reaction with 324 and 326 panpestivirus primers (Fig.2). The eleven positive RNAs were sequentially tested for detection of CSFV, BVDV-1 and BVDV-2 using specific primers. As a result, for all samples were obtained specific amplification signals (211bp PCR product) to BVDV-1 (Fig.3). No positive PCR product was detected after amplification with specific primers for CSFV and BVDV-2.

These results are supported by epidemiological data, infection with BVDV in cattle being wide spread in Romania, seroprevalence rates varying from $20 \%$ to $100 \%$ depending on the region and the size of the herd (Aniță et al. 2008). The presence of the virus has been detected previously using direct immunofluorescence method in 55.5\% (15 out of 27) young unvaccinated bovines (10-16 month of age) raised in household system (Aniță et al. 2009). Moreover, BVDV was detected by real-time RT-PCR in $28.12 \%$ (9 out of 32) Romanian wild boars in 2010 (Turcitu et al. 2010). The

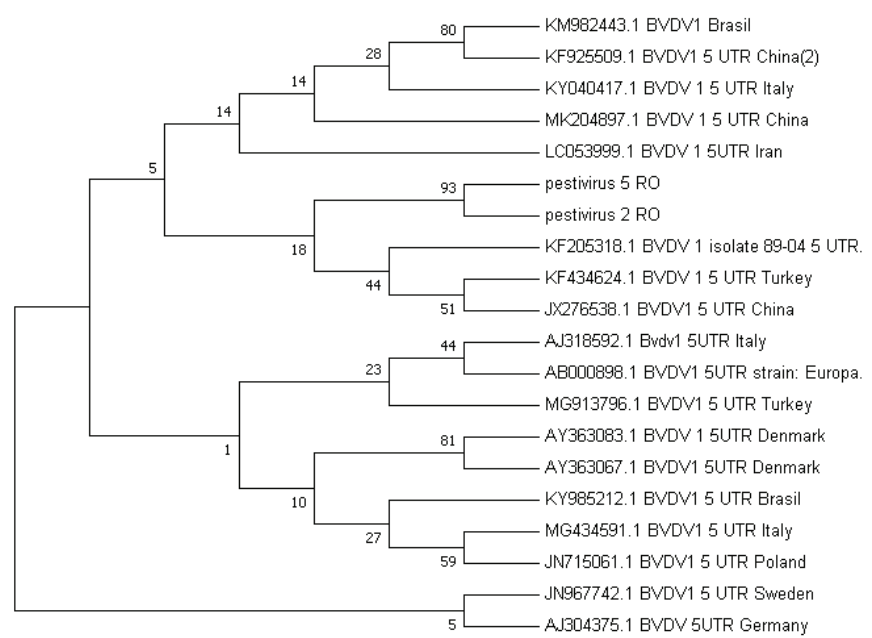

Fig.1. Phylogenetic tree of BVDV-1 sequences. Evolutionary analyses were conducted in MEGA 7 with the bootstrap consensus tree inferred from 1000 replicates. The evolutionary history was inferred using the Neighbor-Joining method (Saitou \& Nei 1987). The evolutionary distances were computed using the Tamura 3-parameter method and are in the units of the number of base substitutions per site (Tamura 1992).

Table 2. Results of the one step RT-PCR using panpestivirus primers

\begin{tabular}{|c|c|c|c|c|}
\hline \multirow{3}{*}{ County } & \multicolumn{2}{|c|}{ No. of animals tested } & \multicolumn{2}{|c|}{ Animals positive for pestivirus RNA } \\
\hline & \multirow{2}{*}{ Wild boars } & \multirow{2}{*}{ Domestic pigs } & Wild boars & Domestic pigs \\
\hline & & & $\%(95 \% \mathrm{CI})$ & $\%(95 \% \mathrm{CI})$ \\
\hline Iași & 150 & 25 & $1.33 \%(-0.50-3.17)$ & $8 \%(-2.63-18.63)$ \\
\hline Vaslui & 85 & 15 & 0 & 0 \\
\hline Bacău & 200 & 52 & $2 \%(0.06-3.94)$ & $5.8 \%(-0.57-12.11)$ \\
\hline Total & 432 & 92 & $1.4 \%(0.29-2.49)$ & $5.4 \%(0.80-10.07)$ \\
\hline
\end{tabular}

CI = Confidence interval. 
negative results on CSFV were expected considering that since 2013, Romania was included in the disease-free countries list for classical swine fever. The last outbreak of CSF was diagnosed on October 2007 and resolved in January 2008. No new case of infection has been registered since 2007. Control and eradication programmes consisted in vaccination against CSF in domestic pigs until November 2009, respectively until December 2011 in wild boars.

Since the first report of ruminant pestivirus detection in naturally infected pigs in 1973 (Fernelius et al. 1973), cases of BVDV infection in swine were described worldwide. Higher rates of seroconversion were detected in pigs located near cattle farms (Paton et al. 1992). In the Netherlands, the BVD prevalence rate was $0.42 \%$ in finishing pigs and $2.5 \%$ for sows (Loeffen et al. 2009). In Poland, BVDV antibodies were detected in $11(68.75 \%)$ out of the 16 provinces, and the seroprevalence varied from $0.1 \%$ to $1.04 \%$ (Lipowski 2014). Studies on BVDV-1 revealed a high prevalence (137 BVDV- positive samples out of 511) in Chinese swine herds were pigs exhibited clinical symptoms (Deng et al. 2012). In Brazil the presence of BVDV infection in domestic pigs has been reported by Almeida et al. (2017) by assessment of BVDV antibodies prevalence in pigs from rearing farms.

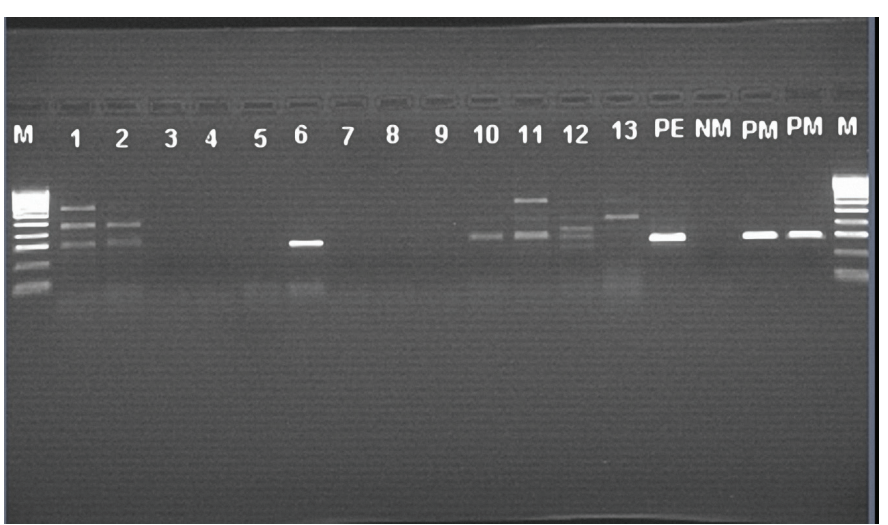

Fig.2. PCR products for one step RT-PCR amplification with panpestivirus primers of swine RNA samples from Iași County. $\mathrm{M}=$ molecular weight marker XIV (Roche), 1 to 13 = swine RNA, PE = positive control (CSFV), $\mathrm{NM}=$ negative control, $\mathrm{PM}=$ positive control (BVDV-1 and BVDV-2).

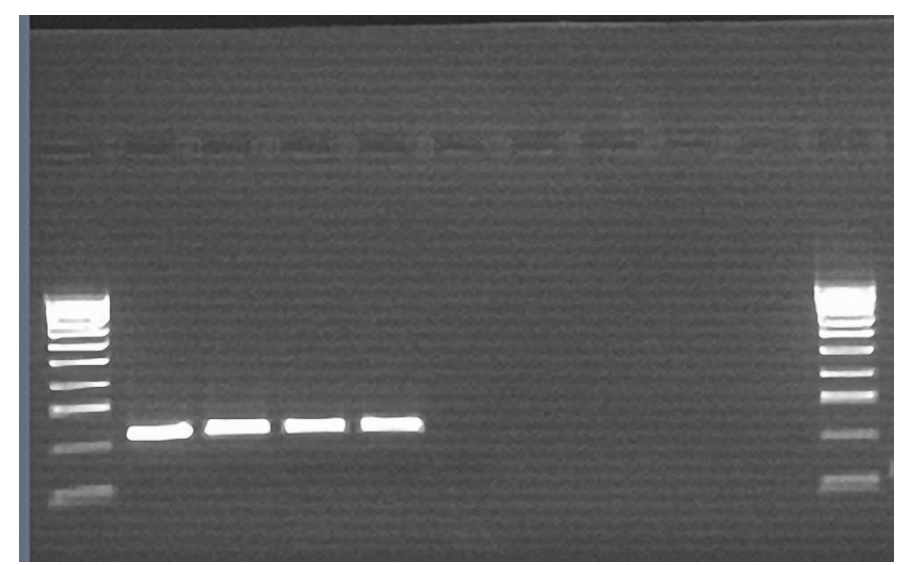

Fig.3. PCR products for one step RT-PCR amplification for BVDV-1 of the four pestivirus positive samples from Iași County. $\mathrm{M}=$ molecular weight marker XIV (Roche).
Our data together with reviewed literature data suggests that wild boars, domestic pigs and ruminants could be sharing bovine diarrhea virus due the similarity of the antigenic structures and that both were reported in the same region. Swine can potentially become sources for BVDV transmission because persistent infection can occur. Our results draw up concerns about the existence of accurate diagnostic tests and questions about risk factors involved in bovine viral diarrhea virus circulation.

\section{CONCLUSIONS}

The present study reported what seems to be the first molecular evidence of BVDV-1 in domestic pigs from Romania.

The pestivirus RNA genome was detected in eleven samples ( 6 wild boars and 5 backyard pigs) out of 527 tested (92 backyard pigs and 435 wild boars), using panpestivirus primers targeting the 5'-UTR region of the pestivirus genome. All eleven RNAs were identified as positives for BVDV-1 and no amplification signals were obtained from BVDV-2 and CSFV.

Our findings highlight the potential of swine (domestic and feral) as reservoir and consequently carrier for bovine diarrhoea virus thus being a signal of awareness for the health management in mixed farms.

Conflict of interest statement.- The authors declare that they have no conflict of interest.

\section{REFERENCES}

Almeida H.M., Gatto I.R.H., Santos A.C., Pereira D.A., Nascimento K.A., Baraldi T.G., Mechler M.L. \& Oliveira L.G. 2017. Bovine viral diarrhea virus infections in pigs: why is this situation important for Brazilian herds? Arqs Inst. Biológico, São Paulo, 84:e0322016. <http://dx.doi.org/10.1590/18081657000322016>

Aniță D., Aniță A. \& Savuța G. 2009. Detection of bovine pestivirus infection (BVDV) using direct immunofluorescence method. Scient. Works, Univ. Agron. Sci. Vet. Med., Bucharest Ser. C, Vet. Med. 55(3):104-108.

Aniță D., Savuța G., Aniță A. \& Merticariu Ș. 2008. Seroepidemiological investigations regarding bovine viral diarrhoea - mucosal disease in the north - east of Romania, Lucr. Șt. USAMVB Timișoara XLI: 326-330.

Deng Y., Sun C.Q., Cao S.J., Lin T., Yuan S.S., Zhang H.B., Zhai S.L., Huang L., Shan T.L., Zheng H., Wen X.T. \& Tong G.Z. 2012. High prevalence of bovine viral diarrhea virus 1 in Chinese swine herds. Vet. Microbiol. 159(3/4):490-493. <http://dx.doi.org/10.1016/j.vetmic.2012.04.023> <PMid:22613254>

Fernelius A.L., Amtower W.C., Lambert G., Mcclurkin A.W. \& Matthews P.J. 1973. Bovine viral diarrhoea virus in swine: characteristics of virus recovered from naturally and experimentally infected swine. Can. J. Comp. Med. 37(1):13-20. <PMid:4265548>

Fletcher S.P. \& Jackson R.J. 2002. Pestivirus internal ribosome entry site (IRES) structure and function: elements in the 5' untranslated region important for IRES function. J. Virol. 76(10):5024-5033. <http://dx.doi.org/10.1128/jvi.76.10.5024-5033.2002><PMid:11967318>

Flores E.F., Ridpath J.F., Weiblen R., Vogel F. \& Gil L. 2002. Phylogenetic analysis of Brazilian bovine viral diarrhea virus type 2 (BVDV-2) isolates: Evidence for a subgenotype within BVDV-2. Virus Res. 87(1):51-60. <http://dx.doi.org/10.1016/s0168-1702(02)00080-1><PMid:12135789>

Giangaspero M. \& Harasawa R. 2011. Species characterization in the genus Pestivirus according to palindromic nucleotide substitutions in the 5'-untranslated region. J. Virol. Methods 174(1/2):166-172. <http://dx.doi. org/10.1016/j.jviromet.2011.04.004><PMid:21514324>

Giangaspero M., Harasawa R., Weber L. \& Belloli A. 2008. Genoepidemiological evaluation of Bovine viral diarrhea virus 2 species based on secondary 
structures in the 5' untranslated region. J. Vet. Med. Sci. 70(6):571-580. <http://dx.doi.org/10.1292/jvms.70.571><PMid:18628597>

Greiser-Wilke I., Depner K., Fritzemeier J., Haas L. \& Moennig V. 1998. Application of a computer program for genetic typing of classical swine fever isolates from Germany. J. Virol. Method 75(2):141-150. <http://dx.doi.org/10.1016/s0166-0934(98)00109-8><PMid:9870589>

Jin Y., Zhiyong H., Jun L., Yunzhen H., Jiongfeng Y., Hongxing D., Jingyuan Z., Mengjiao Z., Yangyi Z., Jiedan L., Mingqiu Z. \& Jinding C. 2017. Atypical porcine pestivirus as a novel type of pestivirus in pigs in China. Front. Microbiol. 8:862. <http://dx.doi.org/10.3389/fmicb.2017.00862><PMid:28553280>

Kirkland P.D., Frost M.J., Finlaison D.S., King, K.R., Ridpath J.F. \& Gu X. 2007. Identification of a novel virus in pigs-Bungowannah virus: A possible new species of pestivirus. Virus Res. 129(1):26-34. <http://dx.doi.org/10.1016/j. virusres.2007.05.002 > <PMid:17561301>

Lipowski A. 2014. Serological study on bovine viral diarrhoea virus infection in pig population in Poland between 2008 and 2011. Bull. Vet. Inst. Pulawy 58:363-368. <http://dx.doi.org/10.2478/bvip-2014-0056>

Liu L., Xia H., Wahlberg N., Belák S. \& Baule C. 2009. Phylogeny, classification and evolutionary insights into pestiviruses. Virology 385(2):351-357. <http://dx.doi.org/10.1016/j.virol.2008.12.004> <PMid:19167739>

Loeffen W.L.A., Van Beuningen A., Quak S. \& Elbers A.R.W. 2009. Seroprevalence and risk factors for the presence of ruminant Pestiviruses in the Dutch swine population. Vet. Microbiol. 136(3/4):240-245. <http://dx.doi. org/10.1016/j.vetmic.2008.11.011><PMid:19128896>

Moennig V. \& Becher P. 2015. Pestivirus control programs: how far have we come and where are we going? Anim. Health. Res. Rev. 16(1):83-87. <http://dx.doi.org/10.1017/S1466252315000092> <PMid:26050577>

Paton D.J., Simpson V. \& Done S.H. 1992. Infection of pigs and cattle with Bovine Viral Diarrhoea Virus on a farm in England. Vet. Rec. 131(9):185188. <http://dx.doi.org/10.1136/vr.131.9.185><PMid:1332247>

Ridpath J.F. \& Bolin S.R. 1998. Differentiation of types 1a, $1 \mathrm{~b}$ and 2 bovine viral diarrhea virus (BVDV) by PCR. Mol. Cell. Probes 12(2):101-106. <http://dx.doi.org/10.1006/mcpr.1998.0158><PMid:9633045>

Saitou N. \& Nei M. 1987. The neighbor-joining method: A new method for reconstructing phylogenetic trees. Mol. Biol. Evol. 4(4):406-425. <http://dx.doi.org/10.1093/oxfordjournals.molbev.a040454><PMid:3447015>
Simmonds P., Becher P., Bukh J., Gould E.A., Meyers G., Monath T., Muerhoff S., Pletnev A., Rico-Hesse R., Smith B.D. \& Stapleton T.J. 2017. ICTV virus taxonomy profile: Flaviviridae. J. Gen. Virol. 98(1):2-3. <http://dx.doi.org/10.1099/jgv.0.000672><PMid:28218572>

Smith D.B., Meyers G., Bukh J., Gould E.A., Monath T., Muerhoff A.S. \& Becher P. 2017. Proposed revision to the taxonomy of the genus Pestivirus, family Flaviviridae. J. Gen. Virol. 98(8):2106-2112. <http://dx.doi.org/10.1099/ jgv.0.000873><PMid:28786787>

Tamura K. 1992. Estimation of the number of nucleotide substitutions when there are strong transition-transversion and $\mathrm{G}+\mathrm{C}$-content biases. Mol. Biol. Evol. 9(4):678-687. <http://dx.doi.org/10.1093/oxfordjournals.molbev. a040752><PMid:1630306>

Tao J., Wang Y., Wang J., Wang J.Y., Zhu G.Q. 2013. Identification and genetic characterization of new bovine viral diarrhea virus genotype 2 strains in pigs isolated in China. Virus Genes 46(1):81-87. <http://dx.doi.org/10.1007/ s11262-012-0837-3><PMid:23085884>

Terpstra C. \& Wensvoort G. 1997. A congenital persistent infection of bovine virus diarrhoea virus in pigs: clinical, virological and immunological observations. Vet. Q. 19(3):97-101. <http://dx.doi.org/10.1080/016521 76.1997.9694750><PMid:9323848>

Turcitu M.A., Bărboi G., Vuță V., Zamfir L., Coste H. \& Boncea D. 2010. Preliminary results regarding bovine viral diarrhea virus epidemiology in Romanian wild boars. Analele Universității Spiru Haret, Seria Medicină Veterinară XI(11):1-5.

Vilcek S., Herring A.J., Herring J.A., Nettleton P.F., Lowings J.P. \& Paton D.J. 1994. Pestiviruses isolated from pigs, cattle and sheep can be allocated into at least three genogroups using polymerase chain reaction and restriction endonuclease analysis. Arch. Virol. 136(3/4):309-323. <http://dx.doi. org/10.1007/BF01321060> <PMid:8031236>

Weber M.N., Streck A.F., Silveira S., Mósena A.C., Silva M.S. \& Wageck Canal C. 2015. Homologous recombination in pestiviruses: identification of three putative novel events between different subtypes/genogroups. Infect. Genet. Evol. 30:219-224. <http://dx.doi.org/10.1016/j.meegid.2014.12.032> $<$ PMid:25562124>

Wieringa-Jelsma T., Quak S. \& Loeffen W.L. 2006. Limited BVDV transmission and full protection against CSFV transmission in pigs experimentally infected with BVDV type 1b. Vet. Microbiol. 118(1/2):26-36. <http://dx.doi.org/10.1016/j.vetmic.2006.06.014><PMid:16979307> 